\title{
Studi Proksemika dan Pengalaman Keruangan Pada Masa Adaptasi Kebiasaan Baru Studi Kasus : Penataan Interior Awor Coffee Yogyakarta
}

\author{
Anugrah A. Pratama1, Suastiwi², St. Sunardi ${ }^{3}$ \\ Universitas Gadjah Mada Yogyakarta \\ Email: anugrah.aji.p@mail.ugm.ac.id
}

\begin{abstract}
Abstrak
Di tengah naiknya pasar kedai kopi, pandemi COVID-19 melanda dan memaksa para pelanggan serta manajemen kafe untuk bertahan dalam situasi tersebut. Dampak pandemi juga dirasakan oleh Awor Coffee sebagai kafe yang cukup lama berdiri di Yogyakarta ini. Masa adaptasi kebiasaan baru yang diungkapkan oleh pemerintah memberikan sedikit jalan keluar bagi industri kafe. Diterbitkannya protokol kesehatan menjadi acuan untuk membiasakan diri dan membantu penekanan penyebaran COVID-19. Inti dari protokol kesehatan adalah pemberian jarak dan pembatasan jumlah tempat duduk. Penelitian ini menganalisa bagaimana sebuah kafe dapat berkompromi dengan protocol kesehatan serta menjabarkan pengalaman yang dirasakan pelanggan selama masa adaptasi kebiasaan baru. Metode kualitatif dan teknik deskripsi analitik digunakan untuk menganalisa permasalahan dengan pendekatan proksemika dan pengalaman keruangan. Hasil penelitian dapat diketahui bahwa untuk menerapkan protokol kesehatan pada sebuah kafe, diperlukan pengetahuan yang cukup terhadap pengguna ruang. Penerapan protokol tidak boleh semata-mata sebagai hal formalitas saja tetapi harus benar-benar dilakukan pendekatan yang tepat. Sehingga hal tersebut berdampak pada pengalaman pelanggannya yang pada akhirnya dapat menerima dan beradaptasi dengan kondisi masa adaptasi kebiasaan baru. Hasil ini dapat menjelaskan bahwa sebuah desain interior tidak dapat berdiri sendiri, diperlukan perpaduan dengan aktivitas ruang sehingga dapat memberikan pengalaman dan menghidupkan suasana ruang interior.
\end{abstract}

Kata kunci: kafe, covid-19, proksemika, pengalaman ruang

\begin{abstract}
In the middle of the coffee shop market popularity, COVID-19 pandemic hits and forces customers as well as cafe management to endure this situation. The impact of the pandemic has also been felt by Awor Coffee as a cafe that has been around for a long time in Yogyakarta. The period of adaptation to new habits revealed by the government provides a little way out for the cafe industry. The issuance of the health protocol is a reference to get used to and help suppress the spread of COVID-19. The core of the health protocol is to provide distance and limit the number of seats. This study analyzes how a cafe can compromise with health protocols and describes the experiences felt by customers during the adaptation period of new habits. Qualitative methods and analytical description techniques are used to analyze problems with a proxemic approach and spatial experience. The results of the study can be seen that to apply health protocols in a cafe, sufficient knowledge of space users is needed. The application of the protocol should not be merely a matter of formality, but the right approach must be taken. So that this has an impact on the customer experience, which in the end can accept and adapt to the conditions of the adaptation period of new habits. These results can explain that an interior design cannot stand alone, it needs
\end{abstract}


a combination with space activities so that it can provide experience and liven up the atmosphere of the interior space.

Keywords: café, covid-19, proxemics, spatial experience

\section{Pendahuluan}

Kafe telah menjadi pilihan masyarakat untuk beraktivitas karena kejemuan mereka terhadap ruang hunian yang semakin sempit. Kafe yang awalnya hanya sebagai tempat makan dan minum sekarang telah berkembang menjadi salah satu alternatif untuk bekerja. Restoran / kafe tidak hanya menjadi tempat untuk memuaskan rasa lapar dan memperoleh layanan, namun juga untuk memperoleh pengalaman berbeda dengan suasana yang unik (Josiam, B. M., \& Henry, W., 2014). Munculnya berbagai aktivitas baru di sebuah kafe menjadikan munculnya interaksi antar pelanggannya. Interaksi tersebut menghasilkan pengalaman dan suasana ruang yang unik. Awor Coffee adalah salah satu kafe yang sukses di Yogyakarta. Awor Coffee yang memiliki manajemen yang telah terstruktur dengan baik dari tahun 2015 dapat melayani kebetuhan makanan, minuman serta ruang kerja bagi pelanggannya. Konsep desain kafe yang simpel dan nyaman menjadi salah satu panutan dari beberapa kafe di kota Yogyakarta. Kesuksesan inilah yang menjadikan Awor pada akhirnya dapat mendirikan beberapa cabang di Yogyakarta.

Pada awal tahun 2020 muncul pandemi Covid-19 di berbagai belahan dunia. Indonesia juga menjadi salah satu negara yang terdampak. Pandemi ini menyerang berbagai sektor, salah satu sektor yang cukup terdampak adalah sektor ekonomi khususnya industri makanan dan minuman. Berbagai industri tersebut banyak yang gulung tikar dikarenakan masyarakat yang takut terkena Covid-19 dan adanya aturan pemerintah tentang pembatasan keluar rumah. Ketika aturan tersebut diterapkan, belum ada regulasi yang jelas untuk kafe. Sehingga banyak kafe yang memilih untuk menutup gerai. Hingga pada akhirnya pemerintah mulai menerapkan masa adaptasi baru dengan diterbitkannya protokol kesehatan. Protokol kesehatan tersebut secara garis besar berisi tentang aturan yang harus diterapkan oleh kafe atau tempat usaha lainnya ketika ingin membuka gerainya. Protokol kesehatan tersebut berfungsi untuk menekan persebaran virus covid-19. Bebarapa aturan yang ada dalam protokol tersebut adalah pembatasan pengguna ruang dan pemberian jarak antar tempat duduk di dalam ruang.

Kafe yang pada awalnya sudah didesain dengan mempertimbangkan berbagai faktor tiba - tiba harus diubah dan menyesuaikan dengan protokol kesehatan. Hal tersebut tentu saja berpengaruh pada suasana ruang yang ada dalam kafe. Suasana yang menjadi daya tarik sebuah kafe dipaksa berubah karena adanya aturan baru. Penataan ruang yang mendadak ini tentu juga berpengaruh terhadap pelanggan. Ruang yang dirasa aman, tiba - tiba menjadi mencekam karena Covid-19. Berdasarkan hal tersebut, pihak manajemen kafe perlu bertindak dengan cepat dan akhirnya menata ulang kembali desain interior Awor sesuai dengan protokol kesehatan. Hal tersebut sangatlah menarik untuk diteliti, desain yang telah direncanakan dengan matang tiba - tiba harus berubah karena situasi alam yang berbahaya.

\section{Metode}

Metode yang digunakan dalam penelitian ini adalah metode kualitatif. Fokus dari penelitian ini adalah memaparkan data yang diolah secara deskriptif analitik. Penelitian ini akan dilakukan di tiga cabang Awor Coffee, yaitu Awor Coffee Yap Square, Awor Coffee Candi Gebang dan Awor Coffee Palagan. Terdapat lima narasumber yang diwawancarai pada tiap cabang sehingga total ada lima belas narasumber. Pada penelitian ini yang menjadi fokus penelitian adalah tentang penataan ruang dan pengalaman yang dirasakan oleh pelanggan di Awor Coffee pada masa adaptasi kebiasaan baru ini. Data penelitian ini dikumpulkan dengan metode (1) Observasi, peneliti turun langsung ke lapangan dan melakukan pengamatan di tiga cabang Awor Coffee yang telah ditentukan. Peneliti mengamati penataan ruang dan elemen - elemen pembentuk ruang yang ada di setiap cabang Awor Coffee. Selama observasi lapangan, peneliti melakukan pemotretan dan 
mencatat aktivitas dan perilaku yang terjadi di Awor Coffee. (2) Wawancara, peneliti melakukan wawancara pada beberapa pelanggan Awor Coffee dan kepada manajemen Awor. Wawancara yang dilakukan adalah wawancara mendalam dan wawancara dilakukan secara mengalir.

Kajian ini diperkuat dengan teori proksemika Edward T. Hall dan pengalaman keruangan yang berasal dari pendapat dari Baraban tentang persepsi ruang dan elemen atmosfer ruang dari Mill.

Proksemika adalah istilah yang diungkapan oleh Edward T. Hall dalam buku The Hidden Dimension dan The Silent Languange. Sumartono mengutip dari Hall menjelaskan bahwa proksemika diartikan sebagai sebuah cara komunikasi nonverbal. Proksemika adalah kajian tentang bagaimana manusia secara tidak sadar membuat struktur ruang mikro-jarak antar manusia dalam melaukan transaksi keseharian dan organisasi ruang (Sumartono., 2012). Hall memiliki tiga konsep utama tentang ruang interpersonal, yaitu :

- Fixed feature space adalah struktur yang tidak dapat dipindah.

- Semi fixed feature space adalah struktur ruang yang dapat dipindah berdasarkan kebutuhan pengguna.

- Informal space adalah teritori ruang diantara tubuh dan sekitarnya.

Setiap interaksi manusia pada ruang akan memiliki jarak interpersonal yang dapat mempengaruhi komunikasi. Sehingga permasalahan proksemika yang terjadi antar manusia dapat dipengaruhi oleh umur, gender, status dan budaya yang mempengaruhi zona interpersonal (Pratiwi, E., \& Aji, N., 2019). Selain ruang interpersonal, Hall membagi empat kategori jarak yang ada dalam proksemika (Hall, E. T., 1966) yaitu :

- Jarak intim $(14-46 \mathrm{~cm})$

Jarak ini seseorang menjaga privasinya. Hanya orang yang dikenal secara emosional yang dapat berada pada jarak ini.

- Jarak personal $(46-120 \mathrm{~cm})$

Jarak antar keluarga dan teman

- Jarak sosial $(120-360 \mathrm{~cm})$

Jarak orang yang tidak begitu saling kenal. Contoh berbicara dengan penjaga toko atau pembicaraan antar kolega.

- Jarak public ( $370 \mathrm{~cm}$ lebih)

Jarak yang digunakan pada diskusi formal. Contoh diskusi dalam kelas.

Yi-Fu Tuan dalam buku Space and Place (Grantham, C. E., \& Tuan, Y.F., 1978)memaparkan bahwa manusia menggunakan panca indranya untuk mempersepsikan sebuah ruang. Mereka mempersepsikan sebuah ruang dengan sesuatu yang pernah mereka rasakan dan kenali. Dari situ mereka akan merasakan emosi terhadap apa yang mereka persepsikan. Sehingga pada akhirnya akan muncul pengalaman ruang yang dihasilkan dari perpaduan antara persepsi dan emosi. Oleh karena itu, untuk membacanya peneliti akan menggunakan pendekatan persepsi ruang dari Baraban dan elemen atmosfer ruang dari Mill. (Baraban, R., \& Durocher, J. F., 2010) menjelaskan bagaimana ruang restoran dapat dipersepsi:

- Distance receptors

1. Visual space, dipengaruhi oleh penglihatan.

2. Auditory space, berkaitan dengan pendengaran, kebisingan ruang.

3. Olfactory space, berkaitan dengan indera penciuman.

- Immadiate receptors

1. Tactile space, berkaitan dengan indera peraba

2. Thermal space, berkaitan dengan suhu ruang.

3. Kinesthetic space, berkaitan dengan kondisi fisik atau luas restoran 
Kemudian untuk membantu membaca pengalaman ruang, peneliti menggunakan elemen atmosfer ruang yang diutarakan oleh Mill (Mill, R., 2007)), yaitu:

- Pengaturan Meja, meliputi penataan barang - barang diatas meja.

- Perabot, membahas mengenai bentuk dan jenis perabot yang dipakai.

- Pencahayaan, membahas tentang suasana yang ditimbulkan oleh lampu

- Warna, mencakup warna yang digunakan dalam sebuah ruang

- Musik, elemen yang membantu membentuk sebuah suasana ruang

- Material Permukaan, membahas material yang digunakan pada perabot dan ruang

- Jarak, mencakup penataan meja dan penggunaan ruang

Kedua pendekatan tersebut bila dipadukan diharapkan dapat membaca pengalaman keruangan yang dirasakan oleh pengguna ruang.

Tabel 1. Persepsi Ruang dan Elemen Pembentuk Ruang Sumber : (Dokumen Pribadi, 2021)

\begin{tabular}{|c|c|}
\hline BARABAN & MILL \\
\hline Distance receptors & \\
\hline Visual Space & Pengaturan meja \\
& Pencahot \\
& Warna \\
\hline Auditory Space & Musik \\
\hline Olfactory Space & - \\
\hline Immediate Receptors & Material permukaan \\
\hline Tactile space & - \\
\hline Thermal space & \\
\hline
\end{tabular}

\section{Pembahasan}

Dalam penelitian ini, pembahasan akan fokus pada analisa proksemika dan pengalaman keruangan. Sehingga pembahasannya akan dibagi kedalam tiga pokok bahasan yaitu (a) pembacaan ruang interior Awor Coffee, (b) proksemika dalam penataan ruang Awor Coffee, (c) membaca pengalamana keruangan pengunjung Awor Coffee.

\section{a. Pembacaan Ruang Interior Awor Coffee}

1. Perabot dan Material

Awor Yap Square menggunakan furnitur yang simpel. Beberapa berasal dari pabrikan dan beberapa lagi membuat sendiri. Bahan yang dipakai berupa kayu, plastik dan semen.

Awor Candi Gebang, juga menggunakan furnitur yang hampir sama dengan Yap Square hanya saja ada kursi yang terbuat dari semen lebih banyak daripada Awor Yap Square. Material furniture yang dipakai pada Awor Candi Gebang adalah kayu, plastik dan semen.

Awor Palagan, memiliki furnitur tanam yang paling banyak. Pada bagian indoor terdapat meja komunal yang terbuat dari semen tanam dan di bagian outdoor terdapat meja 
melingkar yang menjadi ikon dari Awor Palagan. Material yang digunakan masih sama dengan Awor Coffee lainnya.

2. Penataan Meja/Bar

Awor Yap Square, menggunakan meja bar dengan bahan besi dan kayu. Penataan meja barnya cukup simpel. Meja bar Yap Square dibagi menjadi 4 area yaitu slow bar (untuk membuat minuman manual ), fast bar (membuat orderan cepat, menggunakan mesin espresso), cold bar (untuk membuat orderan minuman dingin) dan kasir. Barang - barang diatas meja adalah alat - alat kopi dan produk yang di tawarkan oleh Awor.

Awor Candi Gebang, Meja bar yang ada menggunakan material semen dan ditaman. Sehingga meja tidak dapat digerakan. Meja bar ini mudah dibersihkan karena selama masa adaptasi kebiaaan baru, beberapa barang di atas meja bar dikurangin. Pembagian meja ini juga masih sama dengan Awor Yap Square. Pelanggan dapat duduk depan meja bar untuk bersosialisasi walau pada masa pandemic aktivitas tersebut sangatlah berkurang.

Awor Palagan, mempunyai penataan meja bar yang paling baik menurut manajemen. Meja bar yang nampak luas dan alat - alat seduh kopi yang ditata dengan rapi diatas meja bar menjadi daya tarik bagi pelanggan. Meja bar ini semakin menarik dengan desain lampu plafon yang dibuat menurun mendekati bar. Selama pandemic ini, barang yang ada di atas meja bar juga telah dikurangi sehingga memudahkan untuk membersihkan meja.

3. Pencahayaan dan Warna

Awor Yap Square, memiliki pencahayaan yang sedikit redup dibandingkan dengan cabang lainnya. Warna lampu pada kafe ini berwarna putih dengan sedikit aksen kuning. Sehingga suasana yang terbentuk menjadi nyaman untuk bekerja ataupun nongkrong. Pencahayaan tidak terpengaruh protokol kesehatan tetapi mempengaruhi suasana ruang yang dibentuk oleh manajemen Awor.Sedangkan warna ruang Awor ini memiliki warna coklat pada lantai, dinding berwarna abu - abu dan hitam pada plafond.

Awor Candi Gebang, memiliki pencahayaan natural yang baik. Terdapat banyak jendela pada Awor Candi Gebang karena berada pada sebuah bangunan sendiri. Ketika siang hari, lampu indoor tidak perlu banyak dinyalakan. Warna pencahayaan pada Awor Candi Gebang masih sama dengan Awor Yap Square. Warna putih bersih menjadikan Awor nampak bersih dan menjadi lebih terjaga kebersihannya. Warna yang diusung pada Awor Candi Gebang adalah dominan warna putih dan sedikit aksen warna abu - abu dari material semen

Awor Palagan, memiliki pencahayaan yang tidak kalah baik dengan Awor Candi Gebang, Banyak jendela yang memungkinkan cahaya matahari untuk masuk. Area outdoornya pun dapat terkena sinar matahari. Walaupun memiliki pencahayaan yang baik, ada beberapa bagian indoor yang tetap menyalakan lampu, seperti tempat duduk pelanggan yang berada di sudut ruangan. Untuk warna, Awor Palagan masih mengusung konsep yang sama dengan Awor Candi Gebang. Hanya saja pada area outdoor ada tambahan warna hijau dari tananman disana.

4. Jarak

Awor Yap Square, berada pada komplek ruko Yap Square sehingga menjadikan Awor ini sebagai Awor dengan luas paling kecil. Walaupun begitu penataan yang ada disini 
termasuk baik. Penataan ruang cukup optimal. Pengurangan tempat duduk dan pembatasan jarak menjadikan ruang nampak lebih luas.

Awor Candi Gebang, berada pada bangunan sendiri. Memiliki ruang yang dapat memfasilitasi pelanggan untuk bekerka. Penataan ruangnya pun sengaja untuk di desain untuk bekerja. Meja dan kursi yang memiliki ukuran tepat mendukung ruangan ini menjadi lebih nyaman untuk bekerja. Awor Candi Gebang juga masih dapat memberikan pembagian zona privat dan komunal bagi pelanggannya pada saat pandemi dengan protokolo yang ketat.

Awor Palagan, bertempat pada sebuah bangunan yang berada di jalan kaliurang. Bentuk bangunan yang unik menjadikan Awor Palagan disukai oleh pelanggannya. Awor Palagan memili area yang cukup luas. Pembagian zona ruang pada Awor Palagan juga dapat diterapkan dengan baik. Protokol kesehatan secara tidak langsung dapat membantu dalam penataan ruang ini. Sehingga pelanggan memiliki ruang yang cukup nyaman walaupun di masa pandemi.

5. Musik

Pada ketiga cabang yang diteliti, jenis musik yang diputar memiliki karakteristik yang sama sebab manajemen Awor telah membuat lagu yang siap diputar pada setiap cabang Awor. Lagu yang diputar ada beberapa jenis, instrumental dan lirik. Ketika pagi hari, lagu yang diputar lebih pada musik yang membantu fokus dalam bekerja karena pada pagi hari banyak pelanggan yang datang untuk bekerja. Sedangkan mulai sore hingga malam, lagu yang diputar lebih pada lagu - lagu beat yang enak didengarkan sanbil mengobrol.

\section{b. Proksemika Dalam Penataan Ruang Awor Coffee}

1. Pintu Masuk Utama

Pintu masuk utama menjadi area yang sering dilalui oleh para pelanggan Awor pada setiap cabang karena area ini adalah area masuk dan keluar pelanggan. Pada area ini tidak banyak terjadi interaksi antar pelanggan. Hanya ada interaksi pelanggan untuk mencuci tangan atau menggunakan hand sanitizer. Tidak ada percakapan yang terjadi ketika pelanggan tidak saling kenal. Hal tersebut berlaku pada seluruh cabang Awor yang diteliti. Misal pun terbentuk komunikasi, maka komunikasi yang ada berada pada jarak sosial.

2. Area Bar

Area ini adalah area kerja bagi para pekerja kafe. Pada area ini, biasanya para pekerja atau barista akan membuat menu para pelanggan. Tidak jarang ada pelanggan yang datang ke area bar untuk berbicara dengan barista. Jarak komunikasi yang terjadi biasanya adalah jarak sosial karena pelanggan dan barista biasanya tidak saling kenal tetapi ketika saling mengenal maka jarak komunikasinya akan menjadi jarak personal. Pada masa adaptasi kebiasaan baru ini, jarak komunikasi yang terjadi pada area bar sedikit berubah. Jarak personal yang muncul sedikit mengalami pelebaran zona karena pembatasan jarak pada protokol kesehatan.

3. Area Duduk Indoor

Area Duduk adalah area dimana para pelanggan melakukan aktivitasnya. Para pelanggan akan duduk pada area duduk yang disiapkan oleh Awor Coffee kemudian menikmati menu yang dipesan, mengerjakan pekerjaan dan bercengkerama dengan teman atau pelanggan lain. Setiap cabang Awor memiliki jumlah kapasitas duduk yang 
berbeda - beda tetapi pada dasarnya memiliki fungsi yang sama. Pada masa adaptasi kebiasaan baru ini, pelanggan harus mengikuti protokol kesehatan yang ada. Awor Coffee juga telah menyesuaikan penataan ruang duduk dengan protokol. Beberapa tempat duduk disingkirkan untuk memenuhi pembatasan jarak pada Awor Coffee ini. Manejemen lebih memilih menyingkirkan kursi daripada memberi tanda silang karena dianggap lebih efektif. Pada area ini juga terjadi pergeseran pada jarak komunikasi terutama jarak komunikasi intim dan personal. Dari hasil pengamatan, jarak komunikasi tersebut menjadi lebih berjarak. Percakapan antar teman yang awalnya sudah nyaman pada jarak $46-120 \mathrm{~cm}$ mau tidak mau harus beradaptasi dengan jarak yang baru karena protokol, terlebih pemakaian masker yang menjadikan komunikasi sedikit terkendala. Percakapan antar teman yang saling kenal masih terjadi tetapi percakapan dengan pelanggan lain yang tidak saling kenal menjadi tidak muncul, padahal sebelum pandemi terjadi, percakapan antar pelanggan sering terjadi di dalam ruangan ini.

\section{Area Duduk Outdoor}

Area ini berada di luar ruangan. Pelanggan dapat melakukan aktivias dengan sedikit bebas di area ini. Tempat duduk pada area outdoor lebih banyak ditata sebagai area komunal. Sehingga bagi pelanggan yang datang sendiri mau tidak mau berbagi meja dengan pelanggan lain. Pada masa adaptasi kebiasaan baru ini, area outdoor menjadi pilihan bagi para pelanggan karena adanya aturan yang menghimbau kafe untuk memiliki sirkulasi udara yang baik. Area outdoor dianggap memiliki hal tersebut. Pada area ini, jarak komunikasi yang terjadi juga hampir sama dengan area duduk indoor. Ketika ada seorang pelanggan yang duduk pada salah satu tempat dan telah menciptakan area kerjanya, maka pelanggan lain yang baru datang akan menghargai hal tersebut dengan cara mencari tempat duduk yang lebih berjarak. Pada masa adapatasi kebiasaan baru ini, meja komunal yang bisa dipakai oleh beberapa pelanggan (6 orang) hanya akan dipakai oleh 1-3 pelanggan saja. Hal tersebut menjelaskan bahwa pelanggan mencoba mengikuti protokol yang ada dan memang sadar akan penekanan penyebaran covid. Walaupun terkadang masih ada pelanggan yang kurang mematuhinya karena mereka duduk bersama dengan orang yang dianggap kenal. Untuk interaksi yang terjadi di area outdoor ini.

\section{c. Pengalaman Keruangan Pengunjung Awor Coffee}

Pembacaan pengalaman keruangan pada Awor Coffee dilakukan dengan cara wawancara para pelanggan yang datang ke kafe ini. Selama masa adaptasi kebiasaan baru, telah dijelaskan bahwa Awor Coffee mencoba menyesuaikan penataan ruang kafenya dengan protokol kesehatan yang diberikan. Hal tersebut tentu saja membuat pelanggan memerlukan adaptasi kembali dengan penataan ruang yang telah dilakukan oleh manajemen.

Dimulai dari pengalaman pelanggan terhadap penataan area pintu masuk, pada area ini memang tidak banyak terjadi perubahan ruang. Hanya saja manajemen Awor menambahkan tempat cuci tangan dan meletakan handsanitizer di dekat pintu masuk. Pelanggan yang datang diharapkan untuk mencuci tangan sebelum masuk ke dalam ruangan untuk menekan penyebaran virus covid19. Berdasarkan hasil wawancara, banyak pelanggan yang tidak mempermasalahkan hal ini. Mereka mengikuti saja protokol yang telah diberikan. Pengadaan tempat cuci tangan dengan ember bekas dan terlihat ala kadarnya juga tidak dihiraukan oleh pelanggan.

"ya lebih baik pakai barang bekas aja to mas? Kan itu malah bisa potong biaya produksi selama pandemi. Jadi kita sebagai pelanggan udah dikasi kayak gitu aja udah seneng kok. Jadi itu bikin ngerasa aman aja kl dateng kesini." 
Penuturan pelanggan yang menerima hal tersebut menjadi menggambarkan bahwa sebenarnya Awor Coffee ini sudah memilik brand image yang baik dimata para pelanggannya. Para pelanggan dapat memaklumi suatu hal yang dipaksakan, dalam hal ini dipaksakan secara positif. Tempat cuci yang harusnya tidak ada, dipaksakan oleh manajemen menjadi ada dan hal tersebut diterima oleh pelanggan.

Pada area indoor yang mengalami banyak perubahan penataan ruang, pelanggan juga secara tidak langsung memaklumi perubahan tersebut karena pelanggan sendiri sudah sadar dengan adanya pandemi yang berbahaya ini. Para pelanggan merasa harus tetap menjaga diri supaya tidak tertular. Padahal pada saat penelitian ini dilaksanakan masih ada himbauan dari pemerintah untuk tidak banyak keluar rumah bila tidak diperlukan tetapi para pelanggan ini tetap keluar rumah karena membutuhkan tempat bekerja. Perlu diketahui bahwa pelanggan Awor yang datang pada awal masa adaptasi kebiasaan baru kebanyakan adalah para pekerja lepas yang membutuhkan tempat bekerja dan koneksi internet. Pembatasan jarak dan pengurangan tempat duduk bagi pihak pelanggan tidak begitu dipermasalahkan karena memang mereka butuh tempat yang sepi dan nyaman. Sehingga dapat dikatakan kondisi seperti ini menjadi sedikit positif bagi pelanggan yang membutuhkan tempat bekerja.

"Ini mas salah satu positivnya adanya covid. Bagi orang yang suka datang ke kafe sendiri kayak saya ini. Jadi lebih enak. Kan orang yang datang ke kafe kan jadi sepi. Mau ngerjain apa saja juga bebas"

Penataan ruang yang baru ini dapat memberikan pengalaman baru bagi para pelanggannya. Pelanggan menjadi bisa lebih kondusif dalam bekerja karena area menjadi lebih luang tetapi ada juga pengalaman yang sangat dirindukan oleh para pelanggan sebelum masa pandemi ini yaitu pengalaman tentang ngobrol beramai - ramai antar pelanggan yang ada. Pengalaman baru yang dirasakan para pelanggan ini juga berimbas pada kebiasaan bekerja beberapa pelanggan. Pelanggan bercerita bahwa mereka menjadi punya tujuan yang jelas ketika datang ke sebuah kafe untuk bekerja. Menarget jam kerja dan jam diluar rumah menjadi hal yang timbul karena adanya protokol kesehatan ini.

"kalau selama pandemi ini, saya setiap datang ke kafe akan selalu menarget berapa lama saya bekerja diluar. Dengan begitu perkerjaan jadi lebih cepat selesai dan dapat istirahat dengan cukup di rumah."

Penataan ruang yang mengikuti protokol kesehatan ini secara langsung memang tidak mempengaruhi pelanggan yang datang. Pembatasan jarak yang diterapkan pada penataan furnitur diterima oleh pelanggan karena sadarnya menekan penyebaran virus covid-19. Hanya saja, secara tidak langsung penataan ruang tersebut mempengaruhi pengalaman para pelanggan. Jarak komunikasi yang sedikit berubah dan suasana ruang yang ada membentuk pengalaman dan kebiasaan baru bagi para pelanggan.

Pengelolaan elemen - elemen pembentuk atmosfer ruang dapat membentuk kekayaan pengalaman dari para pengguna ruang. Kebiasaan yang sudah mulai terbentuk karena penataan ruang yang menaati protokol kesehatan adalah menjaga kebersihan diri sendiri tetapi yang lebih penting daripada itu adalah pelanggan yang sudah mulai beradaptasi dengan masa adaptasi kebiasaan baru ini. Sehingga dapat dijelaskan secara singkat bahwa perpaduan penataan ruang dan pembentukan atmosfer ruangan menjadi aspek yang penting dalam membentuk pengalaman seseorang. Pada kasus ini menunjukan bahwa pembiasaan untuk menaati protokol kesehatan dapat dilakukan dengan penataan ruang dan suasana yang mendukung hal tersebut. 


\section{Simpulan}

Kajian ini bertujuan untuk mengetahui proksemika yang terjadi pada penataan ruang Awor Coffee pada masa adaptasi kebiasaan baru dan pengalaman keruangan yang dirasakan pelanggannya. Dari hasil analisa yang telah dilakukan dapat dijelaskan bahwa penataan ruang yang terjadi pada Awor Coffee memperlihatkan suatu bentuk proksemika yang unik. Jarak komunikasi yang fleksibel antar pelanggannya muncul ketika penataan ruang dikondisikan terhadap protokol kesehatan yang ada. Penyesuain protokol kesehatan terhadap kondisi lapangan Awor Coffee menjadi kunci suksesnya penataan ruang ini. Terlihat pada penataan elemen semi fixed feature space, meja kursi dan perabot yang dapat digerakan sesuai kebutuhan, pihak Awor Coffee tidak asal dalam melakukan penataannya tetapi mereka melihat kebutuhan ruang dan kebiasaan dari para pelanggannya. Sehingga walau ada pergeseran jarak komunikasi, para pelanggan masih dapat menerimanya dengan baik dan malah beradaptasi dengan hal tersebut.

Bila berbicara mengenai pengalaman keruangan yang dirasakan oleh pengunjung pada masa adapatasi kebiasaan baru ini. Dapat dikatakan bahwa pelanggan telah mulai dapat beradaptasi dengan penataan ruang dan suasana yang terjadi pada masa adaptasi kebiasaan baru ini. Kebiasaan - kebiaaan baru yang mulai muncul juga menjadi dampak dari penerapan protokol kesehatan pada sebuah kafe. Penataan ruang sendiri dianggap berpengaruh pada pembentukan pengalaman dari pengunjung tetapi yang lebih penting lagi adalah adanya atmosfer ruang yang mendukung terbentuknya suasana kafe secara keseluruhan. Suasana ruang tidak hanya timbul karena adanya penataan saja tetapi diperlukan aktivitas di dalamnya yang turut serta membangun pengalaman bagi para pelanggan.

Dari kesimpulan diatas, dapat dijelaskan secara singkat bahwa dalam menata sebuah ruang, seseorang harus mengetahui detail aktivitas dan kebutuhan dari para pengguna ruang tersebut. Dengan mengetahui detail dengan baik, penataan ruang akan lebih optimal. Dengan begitu, pengguna ruang dapat melakukan aktivitasnya dengan tepat dan dapat membentuk atmosfer ruang yang baik. Sehingga menjadi jelas bahwa untuk mendesain sebuah kafe, pengolahan desain dalam ranah visual saja tidaklah cukup tetapi pengolahan tentang faktor lain yang berhubungan dengan aktivitas dan suasana ruang juga perlu ditekankan secara benar. Sehingga desain kafe tidaklah hanya indah saja tetapi juga dapat memenuhi aktivitas penggunanya dan dapat sewaktu - waktu dapat bedapatasi dengan perubahan yang muncul.

\section{Daftar Pustaka}

Baraban, R., \& Durocher, J. F. (2010). Succesful Restaurant Design. New Jersey: John Wiley and Sons.

Grantham, C. E., \& Tuan, Y.F. (1978). Space and Place: The Perspective of Experience. Diambil kembali dari Contemporary Sociology: https://doi.org/10.2307/2064418

Hall, E. T. (1966). The Hidden Dimension. New York: Doubleday.

Josiam, B. M., \& Henry, W. (2014). Eatertainment: Utilitarian and Hedonic Motivations for Patronizing Fun Experience Restaurants. Diambil kembali dari Procedia - Social and Behavioral Sciences.: https://doi.org/10.1016/j.sbspro.2014.07.287

Mill, R. (2007). Restaurant management : customers, operations, and employees. New Jersey: Pearson, Prentice Hall. 
Lintas Ruang: Jurnal Pengetahuan \& Perancangan Desain Interior | Vol.9 No.1Th.2021 | Hal 27-36

Pratiwi, E., \& Aji, N. (2019). Proxemics Study on The Customer Activity of Bank Mandiri Branch Office Surapati Bandung Based on Customer's Privacy Level. 203-213.

Sumartono. (2012). Proksemika/Semiotika Ruang Sebagai Sebuah Pendekatan Untuk Penelitian Desain Interior. Lintas Ruang, 1-5. 